\title{
STUDENTS' CHARACTERISTICS AS PREDICTORS OF THEIR PERCEPTIONS ON THE EFFECTIVENESS OF COMPUTER-BASED TEST IN NIGERIAN UNIVERSITIES
}

\author{
Oyeronke Olufunmilola Ogunlade (PhD)* \\ Festus Oladimeji Olafare **
}

\begin{abstract}
Computer and related technologies provide powerful tools to meet the new challenges of designing and implementing assessments methods that go beyond the conventional practices. With the growing population of students in most Nigerian Universities, there is need for the use of Computer-Based Test (CBT) for assessment. CBT has long been regarded as a potentially powerful asset for providing assessment. The successes of transition from Paper-Based Test (PBT) to CBT in Nigerian universities prompted this study to investigate students perceptions in this field based on a survey study underpinned by the modified Technology Acceptance Model (TAM) as the research framework. The study is descriptive and the factors that can predict acceptance of CBT for examination in the Nigerian Universities was investigated in a survey study involving 1506 students. The dimensions used in the study were Perceived Ease of Use (PEOU), Perceived Usefulness (PU) and Perceived Credibility (PC). The three dimensions envisage the use of CBT. The study revealed amongst others that the usefulness, ease of use and credibility are important in the' use of computer-based test in Nigerian universities. Based on the result, it was recommended that students' gender and field of study be considered in the use of CBT.
\end{abstract}

Key words: Computer-based test, Technology Acceptance Model, Assessment

\footnotetext{
*Senior Lecturer Educational Technology, Faculty of Education, University of Ilorin, llorin, Nigeria.

** Department of Educational Technology, Faculty of Education, University of Ilorin, Ilorin, Nigeria
} 


\section{INTRODUCTI ON}

Technology with the use of computer has been implemented in the field of education to enhance test delivery system which has been in use in the past. No doubt, technology has significantly added to the advancement in educational testing in a number of ways; it has improved the precision of detecting the actual values of the observed variables; it has helped to make assessment more efficient in different ways: developing tests; making test questions easier to generate automatically or semiautomatically; sharing, reviewing, and revising the questions (Bejar, Lawless, Morley, Wagner, Bennett, \& Revuelta, 2003). It can also help in delivering tests, obviating the need for printing (Bennett, 2002). Technology efficiency of collecting and processing information can enable a good analysis of the available data. It can also support the decision making, and provide the necessary feedback for participants and stakeholders. Technology also helps to detect and record psychomotor, cognitive and affective characteristics of students and the social contexts of teaching and learning processes (Csapó, Ainley, Bennett, Thibaud, \& Nancy, 2010).

Zhang, Powers, Wright and Morgan (2003) asserted that technology is useful for constructing responses on screen, allows marking quality to be monitored in real time and potentially eliminating the need to gather examiners together. In recent time, technology offers many new opportunities for innovation in educational assessment through potentially and powerful scoring, reporting and real-time feedback mechanisms. Universities have implemented numerous attempts and efforts to integrate information and communication technologies (ICT) into administration and instruction process by the creation of the Management Information System (MIS) unit (Mejabi \& Raji 2010). It is on this note that universities integrate part of Information and technology for the purpose of testing the students. Therefore, computer and Internet technologies have been useful for many purposes such as tracking and recording students' information, administration of personnel and accounting, and delivering course contents, announcements and assignments (Bennett, 2009). Computer and related technologies provide powerful tools to meet the new challenges of designing and implementing assessments methods that go beyond the conventional practices and to record a broader repertoire of cognitive skills and knowledge (Olumorin, Fakomogbon, Fasasi, Olawale, Olafare, 2013).

The successes of transition from one test method to another depend on the extent and ability of testing professionals to communicate the benefits and limitations of that test method to stakeholders (J ones, 2000). The use of computers for assessment can provide several benefits for educators and test-takers, as Oladipo (2009) concludes that Computer-Based Test (CBT) is a system which spurs development in education as well as other sectors of the economy. CBT usually assists to ensure that candidate's identity in the examination hall is efficiently cross-checked. Computer-based test (CBT) is an efficient way for test sponsors to provide a secure, consistent environment for certification and licensure as it also enhances students' experience (Abubakar \& Adebayo, 2014). 
Computer-based testing is the use of computers to administer tests. Computer Based Test means the candidate sits in front of a computer, the questions are presented on the computer monitor and the candidate submits the answers through the use of keyboard or mouse. CBT have advantages over Paper-based test, both for lecturers that give the test and for the students who participate in the test. CBT allows for more accurate, secure, rapid and more controlled test administration. Administration of test on the computer helps to minimise almost entirely the use of paper printing. This could also reduce administration costs as well as environmental impact. Also, because computers can successfully mark any objective section (where answers have a clear, binary right or wrong answer) almost instantaneously, the need to pay humans to go through with marking grids is erased. This increases the speed of the results and feedback as well as cutting costs and of course improving the accuracy of marking (Pinner, 2011).

Thurlow, Lazarus, Albus. \& Hodgson, (2010) identified many positive prospects of CBT as: It is more efficient than paper-based tests; a year-round testing; a flexible scheduling; an individualized testing environment; a faster score reporting within approximately two weeks of testing, immediate viewing of scores on screen; convenient to undergraduates, graduates, and the larger university community; ability to access all tests that are demanded by students and the community at large; a worldwide testing opportunities for distance and traveling students; local and centralized registration and billing systems and enhanced consistency and security.

The use of computer-based tests (CBTs) has increased significantly over the last few years. The most common type of CBT is the linear CBT which is a fixed-length computerized assessment that presents the same number of items to each examinee in a specified order and the score usually depends on the number of items answered correctly. Evidently, linear CBT imitates a Paper-based test that is presented in a digital format and pays little or no attention to the ability of individual examinee. Also computerized adaptive testing (CAT) is a special type of computer-based test. Each examinee takes a unique test that is tailored to his/her ability level (van der Linden \& Glas, 2000).

CBT has long been regarded as a potentially powerful asset for providing assessment. Ever since computers were first introduced and adapted to the field of assessment, they have been a valuable aid for scoring, data processing, and even interpretation of test results (Butcher, Perry \& Hahn 2004). Computer and technology today offer myriad ways to enrich test in education both in the classroom and in largescale testing situations. The face of examinations in Nigeria is gradually getting a new look due to the introduction of the CBT system. CBT system has been used by a number of Nigerian universities to conduct their post UTME (Unified Tertiary Matriculation Examination) for prospective students. It all started with the University of Ilorin and Covenant University some years ago.

Computer-based test is expected to heal the setback been faced by the traditional paper-pencil system which has been long associated with inconsistency, fraud, poor delivery, malpractice, insecurity, improper scoring of candidates and so on. Students are also privileged to access their results after examination. This has made the CBT system more efficient in Nigerian universities (I paye, 2009). The use of computers 
are well known and apparent in teaching and learning process, but the integration of testing in education has not yet being fully utilized ( Raikes \& Harding, 2003).

According to Abubakar and Adebayo (2011), CBT is still a new phenomenon in Nigeria. However, in the conduct of examination in Nigeria, it poses a lot of challenges. These challenges were categorised into ten Economic factors, accessibility to Internet; gender equity; software factors, manpower and skills; computer facilities, power failure, poor information infrastructure; poor ICT funding and security factor.

Successful integration of technology into education has been requiring stakeholders to have appropriate perceptions about test mode (Koksal \& Yaman, 2009). The perception of the users of computer-based test determines the uses of computer for test administration. Perception is basically to attach personal meanings to internal and environmental inputs received through the senses and neural impulses (Schunk, 2000). Perception can be influenced by many factors such as customs, habits, education, motivation, gender, and area of specialisation. For users to cope emotionally with CBT, their perception is affected by external variables such as gender. According to Davies (1989) there are various external factors to understand why users accept computer for assessment. Pedersen (2003) identified individual characteristics such as gender and organizational features like (area of specialisation) as external factors that influence users' perception of CBT.

Several studies (Enochsson 2005; Busch 1995; Jackson, Ervin, Gardner and Schmitt, 2001) have suggested that there is a 'technological gender gap' between males and females. The female have been lag behind their male peers in use of computers. Gender is an important variable that influence the use of computer for test administration. Studies like Lenhart, Rainie, and Lewis, (2001) revealed that gender gaps have closed rapidly but one must consider the activities that are dominant for each gender. Lack of computer experience for female users has being cited an important factor in determining their perception about the use of computer for test (Tenson, 2000). Ajunwa (2004) found out gender disparity in ICT favours the male. Other studies like Anaekwe (2000), Madu (2001) found non disparity.

Many studies have suggested that compared to men, women are less likely to adopt new technology and if adopted they tend to use it to a lesser degree than men. Tenson (2000) concluded that users' gender determines their use of technology for test administration. Other factors such as area of specialisation and field of study are included in this study as they also influence users' perception of CBT.

The acceptance of test administered through technology is a result of the acceptance of that technology. This acceptance depend on perception of the users of the technology in terms of how useful the technology is, how easy is it to use and how reliable and credible it is in terms of using it to carry out a task such as test administration. Technology Acceptance Model (TAM) was introduced to determine the perception of lecturers and students based on usefulness, ease of use and the credibility of computer-based test. The framework for this study draws on TAM for its basic model and modified TAM to better reflect the model for lecturers and students perceptions of computer-based test in Nigerian universities. In TAM, perceived ease of use and perceived usefulness are addressed as the most important constructs in predicting information system (IS) acceptance. Many researchers agreed that these two 
constructs are useful and valid in understanding individual's intention to adopt an actual system (Liu, Liao, \& Peng 2005; Nysveen, Pedersen, \& Thorbjornsen, 2005). TAM is one of the most-widely used models on the issue of technology adoption.

Depending on the specific technology context, additional constructs are needed to be proposed in order to reflect the perceptions of computer-based test. Therefore, this study proposed perceived credibility as an additional construct in order to enhance the understanding of students' perceptions of computer-based test in Nigerian universities. Perceived credibility addresses the context of computer-based test and the perceptions of lecturers' and students' that are using it for assessment. More so, perceived credibility has the higher ability to predict and explain the intention of lecturers and students to use computer-based test for assessment.

However, there are limited studies that focused on determining the students' perception of computer-based test. Again, very few studies have focused on using TAM to determine the students' perceptions of CBT. The available relevant studies only focused on the attitude, effectiveness and comparability of paper-based test and computer-based test. This is an indication that studies examining the perception of computer-based test particularly in Nigerian university context seem to have been ignored. Therefore, this study examined students' characteristics as predictors of their perceptions on the effectiveness of computer-based test in Nigerian universities. The contribution of this study to the field of education cannot be underestimated because the use of computer-based test is considered as an innovation to educational research and test administration in Nigeria. The outcomes from this study will provide additional knowledge on computer test administration by reporting the perception of students in Nigerian Universities.

\section{TECHNOLOGY ACCEPTANCE MODEL (TAM) AND COMPUTER-BASED} TEST

Technology Acceptance Model (TAM) is based on the theoretical beliefs-attitudeintention, behaviour causal relationship initially established by Theory of Reasoned Action. Technology Acceptance Model (TAM) is commonly used to explain and predict the acceptance of technology. Technology Acceptance Model is designed to apply to computer usage behavior (Davis, Bagozzi, \& Warshaw, 1989).

Behavioural Intention is a measure of the strength of one's intention to use the computer. Attitude is defined as an individual's positive or negative feelings (evaluative affect) about performing the target behaviour. Subjective norm refers to the person's perception that most people who are important to him think he should or should not make the use of the computer (Fishbein \& Ajzen, 1975).

Based on the belief-attitude-intention-behaviour relationship from Fishbein and Ajzen (1975), Davis proposed TAM for explaining and predicting user acceptance of system. The major contribution of TAM is to measure development with two key beliefs: perceived usefulness and perceived ease of use. Davis (1989) defined perceived 
usefulness as "the degree to which individual believes that using a particular system would enhance his or her job performance," and perceived ease of use as, "the degree to which individual's believes that using a system would be free of effort".

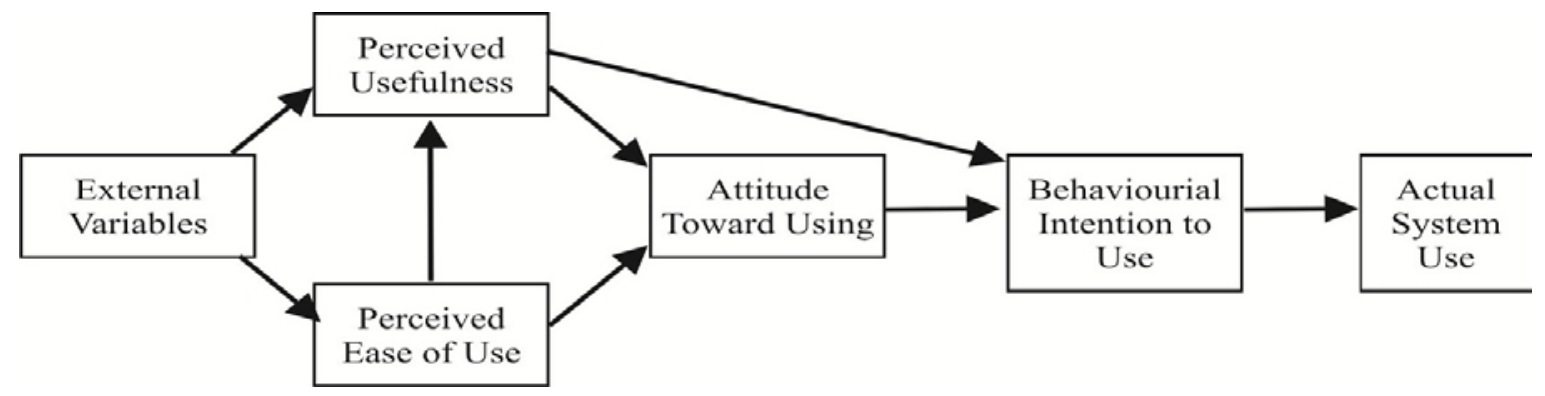

Figure 1: Technology Adoption Model, Source: Technology Acceptance Model (Adapted from Davis, Bagozzi, \& Warsaw, 1989).

Perceived usefulness: This is taken directly from Davis, et al. (1989) and refers to a positive attitude to a system, so that the person will want to use the system again (Davis, 1989, $P$ 279). The importance of perceived usefulness has been widely recognized in the field of education as regard testing of student. The usefulness of computer- based test in this study was determined by how effective and productive the system is when it comes to examination environment and control over examination.

Perceived ease of use: This is also taken directly from Davis et al. (1989) and refers to the degree to which an individual believes that using a system would be free from effort. The easier users perceive the computer-based test to be, the more they tend to form positive attitudes toward using the computer-based test in some form in the future, or using it continuously. The perceived ease of use is measured by its convenience, timeliness and access.

Perceived credibility (added variable): This is concerned with the confidence and consequences associated with a user's actions. Perceived credibility is the degree to which users feel the certainty and pleasant consequences of using computer-based test. This can be measured by the perception of users (lecturers and students) in terms of the outcome of using computer-based test.

TAM perceived usefulness and ease of use are directly determined by external variables, as the external variables pertain to user characteristic and system characteristic. Technology Acceptance Model also suggests the attitude that would be a direct predictor of the intention to use technology as it can also predict the actual usage of the system. Perceived ease of use (expectation that a technology requires minimum effort) and perceived usefulness (perception that the use of a technology can enhance performance of a task at hand) would determine the users intention to use a technology. Technology Acceptance Model is an intention-based model developed for explaining user acceptance of computer technology ( $\mathrm{Hu}$, Chau, Sheng, \& Tam, 1999). Perceived usefulness is the major determinant of individual intentions to use a system, while perceived ease of use is a secondary determinant. Overall, TAM is superior to Diffusion of Innovation Theory (DOI) and Theory of Reasoned Action (TRA) in predicting the user behavior of a system.

Among these theoretical models, the Technology Acceptance Model (TAM) is tailored to study the user acceptance of computer technology. It has been applied across different user 
populations and a broad range of end-user computing technologies, and it has been empirically approved to be a strong model for studying user acceptance of computer-based test. TAM is easier to apply when predicting computer usage. Therefore TAM is used as the main theory in this study, however by the way of modification a construct (perceived credibility) is added to it in this study. TAM is used in this study for the acceptance of the computer as an assessment mode of testing students in Nigerian Universities which is known as computer-based test. The technology Acceptance Model has received great attention in the information technology and information systems literature (Davis, 1989, Davis, Bagozzi, \& Warsaw, 1898). TAM is also considered because it traced the impact of external variables on perceived usefulness, perceived ease of use and perceived credibility.

\section{OBJ ECTIVES:}

The study intended to find out the following objectives:

1. To identify factors that can predict acceptance of CBT for examination in Nigerian Universities.

2. To determine perceived usefulness; ease of use, usefulness and credibility to computer-based tests.

\section{Hypotheses:}

Hol: There is no significant difference in students' perceived usefulness of computer-based test in Nigerian universities based on gender.

$\mathrm{Ho}_{2}$ : There is no significant difference in students' perceived ease of use of computer-based test in Nigerian universities based on gender.

$\mathrm{Ho}_{3}$ : There is no significant difference in students' perceived credibility of computer-based test in Nigerian universities based on gender.

$\mathrm{Ho}_{4}$ : There is no significant difference in students' perceived usefulness of computer-based test in Nigerian universities based on field of study.

$\mathrm{Ho}_{5}$ : There is no significant difference in students' perceived ease of use of computer-based test in Nigerian universities based on field of study.

$\mathrm{Ho}_{6:}$ There is no significant difference in students' perceived credibility of computer-based test in Nigerian universities based on field of study.

\section{I nstrumentation}

Technology Acceptance Model (TAM) proposed by Davis, Bagozzi and washaw (1989) was used in this research after modifing it. There are other factors that influence successful implementation of a system use as researcher have to choose further appropriate measures based on the objective of the study. Based on this argument, appropriate measure of technology use was added to Technology Acceptance model to capture the occurrence in the study, namely lecturers and students perceptions of computer-based test in Nigerian universities. Perceived credibility was added to the construct based on the fact that it is positively related to the use of computer-based test. Pikkarainen, T.; Pikkarainen, K.; Karjaluoto, H. (2004) pointed out that the perceived credibility is needed to be considered to 
investigate the usefulness and ease of CBT. A questionnaire was developed based on items adapted from prior studies that had demonstrated validity and reliability. To fit the context of this study, minor wording adjustments were made to the questionnaire items. Likert scale with 4 options with 1 being strongly disagrees and 4 strongly agree were used

\section{Frame Work of Research}

The factors that influence successful implementation of a system use have some characteristics that are directly associated with the use of the system. These characteristics also determine the use of the system. In this this study, students' gender and field of study which are intervening variables are associated to the factors that influence the actual use of computer-based test. Gender and Field of Study were the intervening variables added to TAM as it is in this study. This was done to capture the influence of the characteristics of the students on their perception about CBT and also to increase the explanatory power of the model. This is on the assumption that this research intended to find out the influence of gender and field of study on the students perceptions of computer-based test for assessment in Nigerian Universities.

Technology Acceptance Model includes "attitude to use and behavioural intention to use". In this study, attitudes to use and behavioral intention from the original Technology Acceptance Model were excluded because the study focused on perceptions of the users and not the attitude to use and behavioural intention to use CBT. Based on Davis et al. (1989) Technology Acceptance Model, a research model for this study is developed as shown in figures

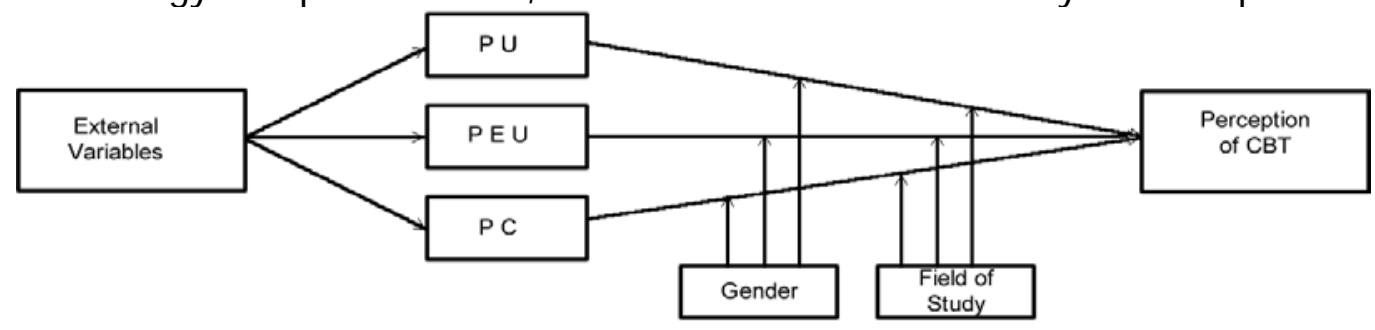

Figure 2: Framework for Students' Perception of CBT

\section{RESEARCH METHODOLOGY}

The research describes the cuurrent situation and survey was conducted to collect the data.

\section{Population:}

Students of universities of Nigeria comprised the population.

\section{Sample:}

A total of 1506 responses were collected from the four selected university (university of Ilorin; Kogi State University; Covenant University and University of Ibadan) making use of CBT.

\section{Data Analysis:}


The results of the administered researcher-designed questionnaire was subjected to inferential statistics and was coded and analyzed using Statistical Package for Social Sciences (SPSS) version $\mathbf{2 0 . 0}$ for windows. The statistical tests used were inferential analysis involving t-test for gender, Analysis of Variance (ANOVA) and Scheffe Post-hoc analysis was employed to test the direction of differences on null hypotheses on field of study respectively.

\section{RESULTS}

In this section, the comparison based on gender and field of study were analysed.

Table 1

Students’ Perceived Usefulness of Computer-Based Test in Nigerian Universities based on Gender

\begin{tabular}{cccccccc}
\hline Variable & $\mathrm{N}$ & $\mathrm{X}$ & $\mathrm{SD}$ & $\mathrm{df}$ & $\mathrm{t}$ & Sig & Remarks \\
& & & & & & & \\
\hline Male & 770 & 38.09 & 6.46 & & & & \\
& & & & 1504 & 6.60 & 0.00 & Rejected \\
Female & 736 & 40.15 & 5.60 & & & & \\
\hline
\end{tabular}

Table 1 , reveals there was a significant difference between male and female students perceived usefulness of computer-based test in Nigerian Universities. This is reflected in the result; df (1504), $t=6.60, p<0.05$. Therefore, the hypothesis which states that there is no significant difference between male and female students' perceived usefulness of computer-based test in Nigerian Universities was rejected. The mean score for the male students (38.09) significantly different from that of the female students (40.15). This therefore implies that the female students' perceived computer-based test usefulness than male students in Nigerian Universities.

Table 2

Students' Perceived Ease of Use of Computer-Based Test in Nigerian Universities based on Gender

\begin{tabular}{cccccccc}
\hline Variable & $\mathrm{N}$ & $\mathrm{X}$ & $\mathrm{SD}$ & $\mathrm{df}$ & $\mathrm{t}$ & Sig & Remarks \\
& & & & & & & \\
\hline Male & 770 & 44.06 & 7.00 & & & & \\
& & & & 1504 & 4.74 & 0.00 & Rejected \\
Female & 736 & 45.84 & 7.54 & & & & \\
\hline
\end{tabular}


From table 2, it can be deduced that there was a significant difference between male and female students perceived ease of use of computer-based test in Nigerian Universities. This is reflected in the result: $d f(1504) t=4.74, P<0.05$. Therefore the hypothesis is rejected. This shows that there is a significant difference between the mean score of male and female students at 0.05 alpha level. The male students mean score (44.06) differ significantly from that of the female students' mean score (45.84). The female students' perceived computer-based test easy to use

\section{Table 3}

\section{Students' Perceived Credibility of Computer-Based Test in Nigerian Universities based on Gender}

\begin{tabular}{|c|c|c|c|c|c|c|c|}
\hline Variable & $\mathrm{N}$ & $X$ & SD & $d f$ & $t$ & Sig & Remarks \\
\hline Male & 770 & 43.00 & 7.45 & & & & \\
\hline & & & & 1504 & 2.60 & 0.01 & Rejected \\
\hline Female & 736 & 42.04 & 6.35 & & & & \\
\hline
\end{tabular}

Table 3 reveals there was a significant difference between male and female students' perceived credibility of computer-based test in Nigerian Universities. This is reflected in the result; df (1504) $t=2.60, P<0.05$. Therefore the hypothesis is rejected. This shows that there is a significant difference between the mean score of male and female students at 0.05 alpha levels. The mean score of male students (43.00) was significantly different from that of the female students (42.04). The male students' perceived computer-based test credible than female students in Nigerian Universities.

Table 4

Students’ Perceived Usefulness of Computer-Based Test in Nigerian Universities based on field of study (Humanities, Pure Science and Applied Science)

\begin{tabular}{lrrrrr}
\hline & $\begin{array}{l}\text { Sum of } \\
\text { Squares }\end{array}$ & df & Mean Square & F & Sig. \\
\hline Between Groups & 3271.164 & 2 & 1635.582 & 46.02 & .00 \\
Within Groups & 53416.292 & 1503 & 35.540 & & \\
Total & 56687.456 & 1505 & & & \\
\hline
\end{tabular}

From table 4 , it was reveal that $\mathrm{F}(2,1503)=46.02, \mathrm{P}<0.05$ for the students' perceived usefulness of Computer-Based Test in Nigerian Universities based on field of study was significant. The result shows that there was a significant difference in students' perceived usefulness of Computer-Based Test in Nigerian Universities based on their field of study. Since it was shown in table 29 that there was a significant difference in students' perceived usefulness 
of Computer-Based Test in Nigerian Universities, Scheffe's post-hoc analysis was used to locate the direction of the difference among the groups. This was to establish whether there is a difference in students' perceptions based on their field of study. Table 51 therefore shows the result of the analysis using Scheffe's post-hoc and the mean score difference was at 0.05 level.

Table 5

Scheffe's Analysis of Significant Difference on Students' Perceived Usefulness of ComputerBased Test in Nigerian Universities based on Field of study (Humanities, Pure Science and Applied Science)

\begin{tabular}{lllccc}
\hline & (I) Field of Study & $(\mathrm{J})$ Field of Study & $\begin{array}{c}\text { Mean } \\
\text { Difference } \\
(\mathrm{I}-\mathrm{J})\end{array}$ & Std. Error & Sig. \\
& & $-3.63^{*}$ & .379 & .000 \\
& \multirow{3}{*}{ Humanities } & pure science & $-1.64^{*}$ & .365 & .000 \\
& & applied science & $3.63^{*}$ & .379 & .000 \\
\multirow{3}{*}{ Scheffe } & pure science & Humanities & $1.99^{*}$ & .393 & .000 \\
& & applied science & $1.64^{*}$ & .365 & .000 \\
& \multirow{2}{*}{ applied science } & Humanities & $-1.99^{*}$ & .393 & .000 \\
& & pure science & & & \\
\hline
\end{tabular}

* Significant at 0.05

The Scheffe's post-hoc analysis on perception of the three fields of study in table 5 implied that there was a significant difference between Humanities and pure science. There was also a significant difference between humanities and applied science. There was even a significant difference between pure science and applied science. Hence, Scheffe's analysis established that there was a significant difference in students' perceived usefulness of computer-based test in Nigerian universities is different based on their field of study.

Table 6

Students' Perceived Ease of Use of Computer-Based Test in Nigerian Universities based on field of study (Humanities, Pure Science and Applied Science)

\begin{tabular}{|c|c|c|c|c|c|}
\hline & $\begin{array}{l}\text { Sum of } \\
\text { Squares }\end{array}$ & $\mathrm{df}$ & $\begin{array}{l}\text { Mean } \\
\text { Square }\end{array}$ & $\mathrm{F}$ & Sig. \\
\hline Between Groups & 2751.007 & 2 & 1375.503 & 26.54 & 0.00 \\
\hline Within Groups & 77909.532 & 1503 & 51.836 & & \\
\hline Total & 80660.539 & 1505 & & & \\
\hline
\end{tabular}


From table 6 , it was revealed that $\mathrm{F}(2,1503)=26.54, \mathrm{P}<0.05$ for students' perceived ease of use of Computer-Based Test in Nigerian Universities based on field of study was significant. The result reveals that there was a significant difference in the students' perceived ease of use of Computer-Based Test in Nigerian Universities based on the field of study. Since it was shown in table 31 that there was a significant difference in students' perceived ease of use of Computer-Based Test in Nigerian Universities, Scheffe's post-hoc analysis was used to locate the direction of the difference among the groups. This was to establish whether there was difference in students' perceptions of computer-based test based on their field of study. Table 7 shows the result of the analysis on Scheffe's post-hoc.

\section{Table 7}

Scheffe's Analysis of Significant Difference on Students' Perceived Ease of Use of Computer-Based Test in Nigerian Universities based on Field of Study (Humanities, Pure Science and Applied Science)

\begin{tabular}{lllccc}
\hline & $(\mathrm{I})$ Field of Study & $(\mathrm{J})$ Field of Study & $\begin{array}{c}\text { Mean } \\
\text { Difference }(\mathrm{I}- \\
\mathrm{J})\end{array}$ & Std. Error & Sig. \\
\hline \multirow{3}{*}{ Humanities } & pure science & .77 & .456 & .242 \\
& & applied science & $2.07^{*}$ & .439 & .000 \\
Scheffe & pure science & Humanities & -.77 & .456 & .242 \\
& & applied science & $1.30^{*}$ & .474 & .023 \\
& \multirow{2}{*}{ applied science } & Humanities & $-2.07^{*}$ & .439 & .000 \\
& & pure science & $-1.30^{*}$ & .474 & .023 \\
\hline
\end{tabular}

* Significant at 0.05

From the Scheffe's post-hoc analysis on perception of the three fields of study in table 7, it could be deduced that there was a significant difference between humanities and pure science. It could also be deduced that there was a significant difference between humanities and applied science. Scheffe's post-hoc analysis showed that there was no significant difference between pure science and applied science.

Table 8

Students' Perceived Credibility of Computer-Based Test in Nigerian Universities based on Field of Study (Humanities, Pure Science and Applied Science)

\begin{tabular}{llllll}
\hline & Sum of Squares & Df & $\begin{array}{l}\text { Mean } \\
\text { Square }\end{array}$ & F & Sig. \\
\hline Between Groups & 1156.936 & 2 & 578.468 & 11.23 & .00 \\
Within Groups & 77456.279 & 1503 & 51.534 & &
\end{tabular}


From table 8 , it was reveal that $\mathrm{F}(2,1503)=11.23, \mathrm{P}<0.05$ for students' perceived credibility of Computer-Based Test in Nigerian Universities based on field of study was significant. The table reveals that there was a significant difference in students' perceived credibility on Computer-Based Test in Nigerian Universities based on field of study. Scheffe's post-hoc analysis was used to locate the direction of the difference among the groups. This was to establish whether there is a difference in students' perceptions based on their field of study.

\section{Table 9}

Scheffe's Analysis of Significant Difference on Students' Perceived Credibility of Computer-Based Test in Nigerian Universities based on Field of Study (Humanities, Pure Science and Applied Science)

\begin{tabular}{llllll}
\hline & (I) Field of Study & $(\mathrm{J})$ Field of Study & $\begin{array}{l}\text { Mean } \\
\text { Difference }(\mathrm{I}-\mathrm{J})\end{array}$ & Std. Error & Sig. \\
& & & & \\
& \multirow{2}{*}{ Humanities } & pure science & .77 & .456 & .242 \\
& & applied science & $2.07^{*}$ & .439 & .000 \\
Scheffe & pure science & Humanities & -.77 & .456 & .242 \\
& & applied science & $1.30^{*}$ & .474 & .023 \\
& & Humanities & $-2.07^{*}$ & .439 & .000 \\
& applied science & pure science & $-1.30^{*}$ & .474 & .023 \\
\hline
\end{tabular}

* Significant at 0.05

Table 9 reveals that there was no significant difference between humanities and pure science. It was also deduced that there was a significant difference between humanities and applied science. Scheffe's post-hoc analysis showed that there was a significant difference between pure science and applied science. Hence, Scheffe's analysis established a significant difference in students' perceived credibility of computer-based test in Nigerian Universities based on their field of study. 


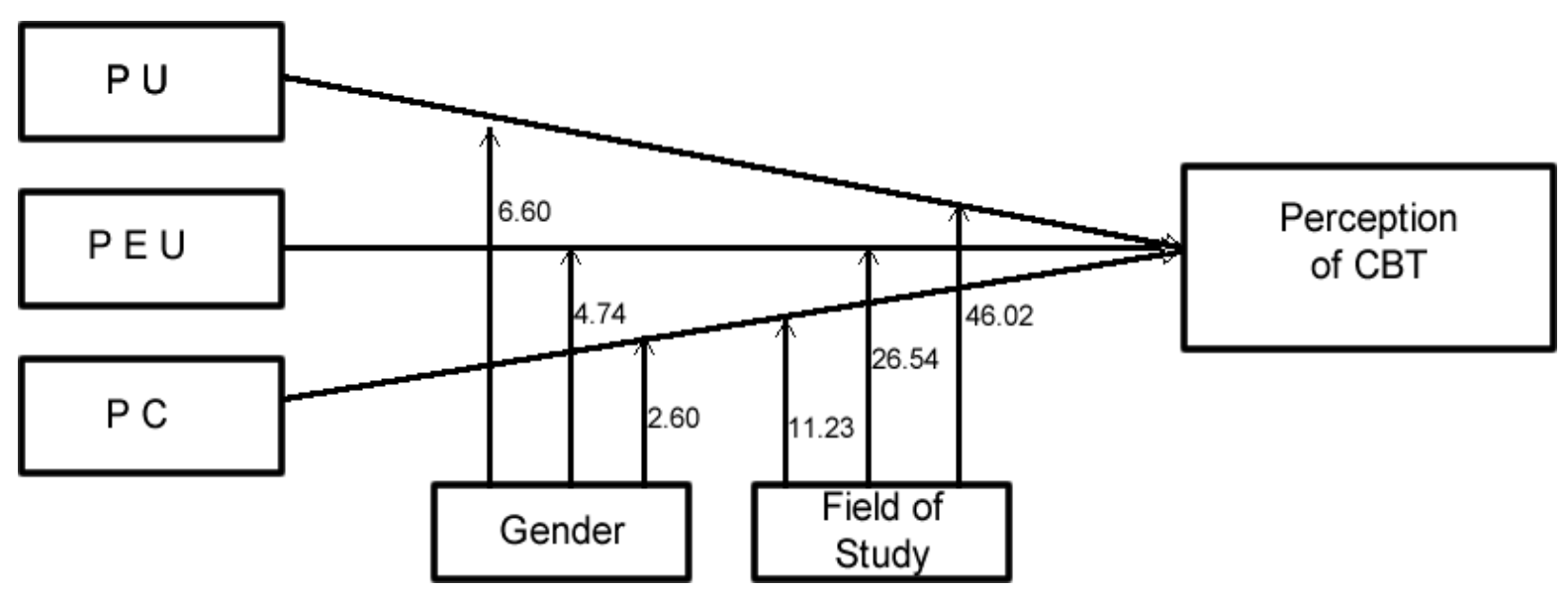

Figure 3: Resulting Model for Students Perception of CBT

\section{DISCUSSION}

The result of this finding agrees with Gallagher et al. (2002). The researchers reported that gender difference was found in the use of CBT for test. Gallagher et al. reported that female obtain lower scores on computerized assessments. There has reported a significant gender difference in favour of girls on all subsections of a baseline test in literature. George reported that male students perceived CBT differently from female students. The study also agreed with the findings of kirkPatrick and Cuban (1998) who reported gender differences in the attitude towards the use of computer-based test.

However, the result of this study contradicts the report of Bennett (2009); Clariana and Wallace (2002) who reported that there is no difference in the administration mode of computer-based test based on gender.

\section{I mplications of the Findings}

Technology Acceptance Model (TAM) was modified for the purpose of this study and the setting in which the study was conducted. The modification led to the introduction of other variable, to reflect the effectiveness of computer-based test in Nigerian universities. As a result, the model was adapted with the inclusion of gender, area of specialization and field of study as intervening variables and perceived credibility as an added construct to perceived usefulness and perceived ease of use. More so, gender and field of study should be considered when using computer-based test.

Researchers who have worked in this area have made use of available relevant Technology Acceptance Model. The same thing was done in this study by making use of the Technology Acceptance Model. This was done by way of modifying the model to suit the purpose and context in which the study was conducted. The modification led to the introduction of variables such as gender and field of study as external variables. Perceived credibility was 
also added to reflect the effectiveness of computer-based test in an educational setting. See

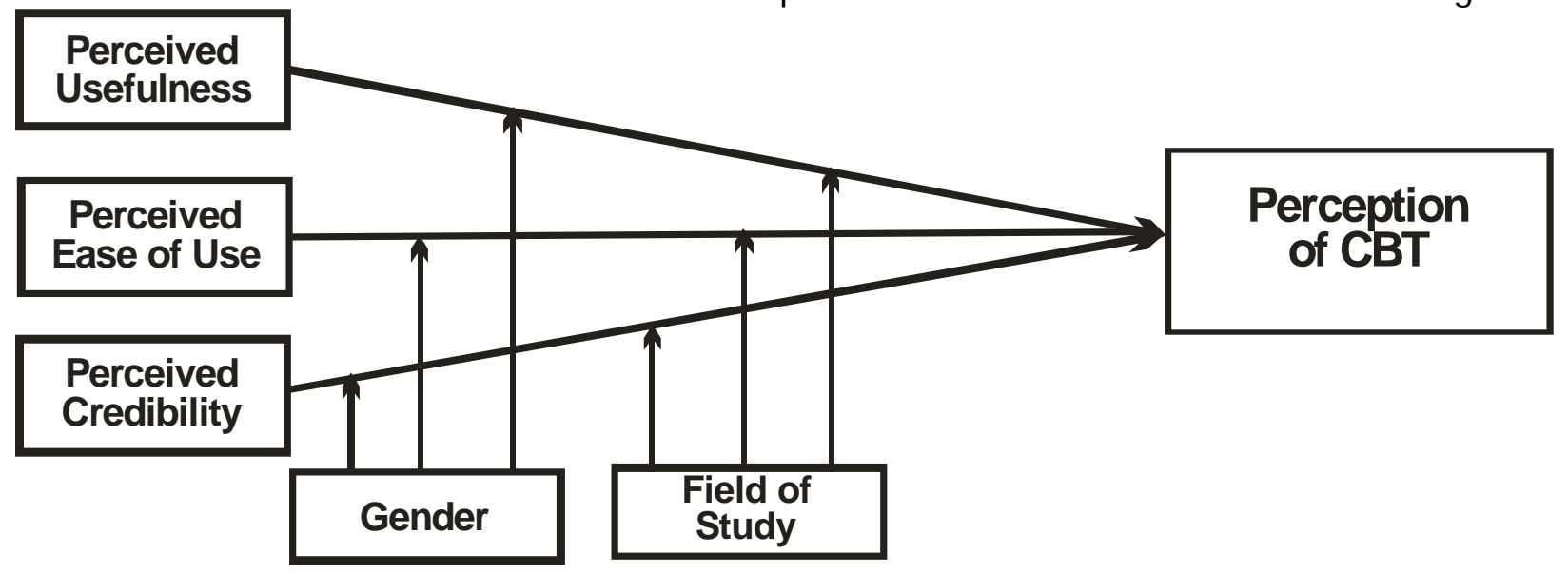

Figure 4: Derived Modification of TAM Model on CBT.

\section{Conclusions}

The study proposed model tested the perceived usefulness, ease of use and credibility based on the characteristics (gender and field of study). In light of this, the study discovered that the usefulness, ease of use and credibility are evident in the' use of computer-based test in Nigerian universities. The study reveals a significant difference in the students perceived usefulness, perceived ease of use and perceived credibility based on gender and field of study. This implies that computer-based test is perceived as useful to male and not to female; it is perceived as easier to use for male and not to female. This study has shown that there is room for modification of Technology Acceptance Model by addressing the variables that determines utilization of CBT and to test the characteristics that contribute to the use of CBT.

\section{Recommendations and future work}

Based on the findings and conclusions, it was recommended that the proposed model can be used for other related studies on perceptions of computer-based test; Nigerian universities should improve the efficiency of computer-based test to increase its credibility.

\section{REFERENCES}

Abubakar, A. S. \& Adebayo F. O.(2014). Using Computer Based Test Method for the Conduct of Examination in Nigeria: Prospects, Challenges and Strategies. Mediterranean Journal of Social Sciences, 5 (2) 47-56.

Andrew, F., Pullen, D. \& Harpen, C. (2009). Case study of a computer based examination system. Australasian Journal of Educational Technology, 25(4), 509-523

Bejar, I. I., Lawless, R. R., Morley, M. E., Wagner, M. E., Bennett, R. E., \& Revuelta, J. (2003). A feasibility study of on-the-fly item generation in adaptive testing. Journal of 
Technology, Learning and Assessment, (3).

Retrievedfromhttp://www.bc.edu/research/intasc/jtla/journal/v2n3.shtml on 22, july 2012

Bennett, J. (2002). Exploration of a Gap: Strategizing Gender Equity in African Universities. Feminist Africa, 1.

Bennett, R. E. (2009). A critical look at the meaning and basis of formative assessment. Princeton, NJ: Educational Testing Service.

Butcher ل. N., Perry L., \& Hahn 1. (2004). Computers in clinical assessment. Historical developments, present status, and future challenges. Educational Technology \& Society.

Busch, T. (1995).Gender differences in self-efficacy and attitudes toward computers. Journal of Educational Computing Research, 12,147-158.

Clariana, R. B. \& Wallace, P.E. (2002). Paper-based versus computer-based assessment: Key factors associated with the test mode effect. British J ournal of Educational Technology, 33 (5), 595-904.

Csapó, B. Ainley, J. Bennett, R. Latour, T. \& Law, N. (2010). Draft of white paper 3 technological issues for computer-based assessment. A report to the Learning and Technology World Forum in London.

Davies, F. D. (1989). Perceived usefulness, Perceived Ease of Use and User Acceptance of I nformation Technology. MIS Quarterly 13(3), 319-339.

Davis, F.D., Bagozzi, R.P. and Warshaw, P.R. (1989) User acceptance of computertechnology - a comparison of 2 theoretical-models, "Management Science", Vol. 35, No. 8, pp 982-1003.

Enochsson, A. B. (2005). A gender perspective on internet use: Consequences for information seeking. Information Research, 10(5), 1-11.

Gallagher, P. D. An investigation of instructional treatments and learner characteristics in a computer-managed instruction course (Doctoral dissertation, Florida State University, 1970)

Dissertation Abstracts International, 1971, 31 (9-A), 4543. (University Microfilms No. 717013)

I paye, B. (2009). E-Learning in a Nigerian Open University. National Open University of Nigeria, 2, 1-11. 
Jackson, L. A., Ervin, K. S., Gardner, P. d., \& Schmitt N. (2001). Gender and the Internet: women communicating and men searching. Sex Roles: A Journal of Research, 44(56), 363-379.

Jones, J. P. (2000). Promoting stakeholder acceptance of CBT.Paper presented at the computer-based testing applications for the new millennium by the Association of Test Publishers, New York.

Kirkpatrick, H., and Cuban, L. (1998), "Computers Make Kids Smarter -- Right?", TECHNOS Quarterly for Education and Technology, 7(2), 1-11.

Koksal, M. S. \& Yaman, S (2009). An Analysis of Turkish Prospective Teachers' Perceptions about Technology in Education. Turkish on line Journal, 15 (2). Retrivedfromhttp://www.uv.es/RELIEVE/v15n2/RELIEVEv15n2 3.htm, 20sept2012.

Lenhart, A., Rainie, L., \& Lewis, O. (2001). Teenage life online: The rise of the instant- message generation and the internet's impact on friendships and family relationships. Washington, DC: Pew Internet and American Life Project.

Mejabi, O. V. \& Raji .S. A. (2010). Contributions of information and communication technology (ICT) to institutional management and academic work: the Unilorin experience. 50 years of university education in Nigeria, evolution, achievement and future directions, A publication of University of Ilorin and National University Commission.

Oladipo, T. (2009). More tertiary institutions embrace electronic testing. Retrieved from eTC Intranet Portal Copyright 28 march 2009.

Olumorin, O. C., Fakomogbon, A. M., Fasasi, A. Y., Olawale, O. C., Olafare, O. F. (2013). Computer based tests: a system of assessing academic performance in university of Ilorin, Ilorin, Nigeria. American Academic \& Scholarly Research Journal, 5 (2), 201-204.

Pikkarainen, T.; Pikkarainen, K.; Karjaluoto, H. (2004), Consumer acceptance of online banking: An extension of the Technology Acceptance Model., Internet ResearchElectronic Networking Applications and Policy, 14(3): 224-235

Pinner, R (2011). Computer-Based Testing Vs. Paper-Based Testing: What are the advantages, disadvantages and what is the future of language testing? International Journal of Electrical \& Computer Sciences, 10(1), 56-59 
Schunk, D. H. (2000). Motivation for achievement: Past, present, and future. Issues in Education, 61/2), 161-166. In Singleton C.H. (2001) Computer-Based Assessment in Education. Education and Child Psychology, 18, 58-74.

Tenson, J. (2000). Teachers ICT skills and knowledge needs. Report on study conducted for SOEID. Aberdeen: The Gordon University.

Thurlow, M., Lazarus S. S., Albus D. \& Hodgson J. (2010). Computer-based Testing. Cites and Considerations, Synthesis Report 78.

Van der Linden, W. J., \& Glas, C. A. W. (Eds.). (2000). Computer adaptive testing: Theory and practice. Boston, MA: Kluwer.

Zhang, Y., Powers, D. E., Wright, W., \& Morgan, R. (2003). Applying the Online Scoring Network (OSN) to Advanced Placement Program (AP) tests. Educational Testing Service.Princeton, NJ: Retrieved August 17, 2012 from http://www.ets.org/research/researcher/RR-03-12.html 